\title{
THE USAGE Of HENNA LEAVES (LAWSONIA INERMIS) FOR DYEING IN COTTON
}

\section{Rupashinii A/P Thana Singam}

Department of Mechanical Engineering Technology, Faculty of Engineering Technology University Tun Hussein Onn Malaysia (UTHM), Hub Pendidikan Pagoh, KM 1, Jalan Panchor,84600 Pagoh Muar, Johor

Malaysia

\section{Noraini BT Marsi*}

Department of Mechanical Engineering Technology, Faculty of Engineering Technology University Tun Hussein Onn Malaysia (UTHM), Hub Pendidikan Pagoh, KM 1, Jalan

Panchor,84600 Pagoh Muar, Johor Malaysia

\section{Nur Athirah BT Huzaisham}

Department of Mechanical Engineering Technology, Faculty of Engineering Technology University Tun Hussein Onn Malaysia (UTHM), Hub Pendidikan Pagoh, KM 1, Jalan

Panchor,84600 Pagoh Muar, Johor Malaysia

\section{Muhammad Haikal B Mohd Fodzi}

Department of Mechanical Engineering Technology, Faculty of Engineering Technology University Tun Hussein Onn Malaysia (UTHM), Hub Pendidikan Pagoh, KM 1, Jalan Panchor,84600 Pagoh Muar, Johor Malaysia

*Corrosponding author's Email: mnoraini@uthm.edu.my 


\section{$R_{i}$}

\section{Science Proceedings Series \\ (SPS) \\ www.readersinsight.net/SPS}

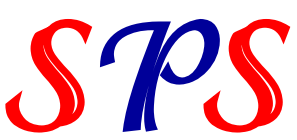

\section{R E S E A R C H H I G H L I G H T S}

This research will be focused on the utilization of henna leaves for the dyeing in cotton fabrics. The formulation of henna dye is capable for the dyeing on the cotton replace the chemical dye. Moreover this research was conducted to reduce the usage of chemical dyes that contact the human body with the natural pigment using extraction method. However the usage of the synthetic dyes can reduce the harmful effect to the human health and environment. The henna leaves have various advantages because it is non carcinorgenic and environment friendly. The composition of natural dyes for the dyeing process on the cotton fabrics are $10 \mathrm{~g}, 20 \mathrm{~g}, 30 \mathrm{~g}, 40 \mathrm{~g}, 50 \mathrm{~g}, 60 \mathrm{~g}, 70 \mathrm{~g}$ and $80 \mathrm{~g}$ with $40 \mathrm{ml}$ of distilled water. The physical test involved was viscosity (ASTM D445-18). Furthemore, the $80 \mathrm{~g}$ of henna leaves with $40 \mathrm{ml}$ of distilled water have higher viscosity compared to the other concentrations.

Keywords: Cotton, Henna, Natural, Synthetic, Textile

\section{RESEARCH OBJECTIVES}

The aim of this paper is to give the overview about the natural pigments which can used as a dye for the dyeing process as replacement for the synthetic dyes. The natural dyes are ecofriendly and noncarcinogenic to the human and environment [2]. Apart from that, nowadays researcher are searching for the natural dyes and reduce the usage of synthetic dyes in the dyeing industry and produce more greener environment. Most of these natural dyes have also inherently antimicrobial properties and could consequently possess high medicinal activity. Dyes are extracted from different types of plants that contain coloring materials such as tannin, lawsone and flavoniods [3]. National and international awareness about depletion of natural resources, ecological imbalance, pollution problem and our disturbed environment due to the ample usage of hazardous chemicals and particularly synthetic dyes have forced people to think safer alternative [4]. Synthetic dyes are not only toxic and harmful to human skin but also to our environment. Therefore these factors have brighten the scope of utilization of natural dyes. The research objectives are to prepared natural dyes based on henna leaves for the cotton fabrics and to evaluate the physical testing on dyed cotton fabrics for textile application.

\section{MATERIALS AND METHODS}

The materials are henna leaves, distilled water, pestle and mortar, dyeing pot and dyeing machine. All the raw material were prepared and weighed according to the composition as $10 \mathrm{~g}, 20 \mathrm{~g}, 30 \mathrm{~g}, 40 \mathrm{~g}, 50 \mathrm{~g}, 60 \mathrm{~g}, 70 \mathrm{~g}$ and $80 \mathrm{~g}$ of henna leaves [1]. Then $40 \mathrm{ml}$ of distilled water was added when the henna leaves in the mortar and the leaves were crashed using the pestle. Moreover the solution was extracted by using filter paper. Next, the solution was poured on the dyeing pot. The cotton fabric size was cut into $11 \mathrm{~cm} \times 14 \mathrm{~cm}$ followed the standard size and the fabric was immersed on the dyeing pot. Then, the dyeing pot was put in the dyeing machine for $90^{\circ} \mathrm{C}$ and about 60 minutes. The cotton fabrics were dried for 30 minutes in the environment. Then, the superhydrophobic coating was coated on the top of dyed cotton fabrics.

\section{RESULTS}

The viscosity of the $80 \mathrm{~g}$ of the henna leaves was 1.44 Pas. The viscosity for the $10 \mathrm{~g}$ of henna leaves and $40 \mathrm{ml}$ of distilled water was $0.12 \mathrm{Pas}$ and $40 \mathrm{~g}$ was $0.26 \mathrm{Pas}$ respectively. The $80 \mathrm{~g}$ of 


\section{$R_{i}$}

\section{Science Proceedings Series (SPS) \\ www.readersinsight.net/SPS}

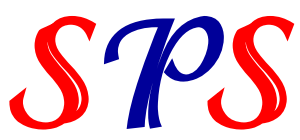

the henna leaves and $40 \mathrm{ml}$ of distilled water has higher viscosity reading compared to the other concentration. This is because the solution inside the $80 \mathrm{~g}$ produce very concentrated solution compared to $70 \mathrm{~g}$ of henna leaves and $40 \mathrm{ml}$ of distilled water [5].

\section{FINDINGS}

The purpose for the project of utilization of Lawsonia Inermis was basically to produce a natural pigment that may not harm the environment. This is because the materials used is taken from natural resources such as plant. The reason why the pigments can be said as environment friendly. Besides that, the study is conducted to produce a pigment that can be applied on cotton fabric for any particular purpose such as to produce technical textiles. This is because, the fabric that going through the pigmentation process was expected to be more resistance to water, having low porosity, stronger than the other fabrics.

\section{ACKNOWLEDGEMENT}

The authors would like to thank the Universiti Tun Hussein Onn Malaysia for supporting this project under Contract Grant by UTHM Scheme under Vot H339.

\section{REFERENCES}

1. Adeel, S., Rehman, F., Rafi, S., \& Zia, K. M. Environmentally Friendly Plant-Based Natural Dyes : Extraction Methodology and Applications (Vol. 2), 2019

2. Chauhan, S., Sheo, L., \& Upadhyay, B. Biosynthesis of iron oxide nanoparticles using plant derivatives of Lawsonia inermis ( Henna) and its surface modification for biomedical application. Nanotechnology for Environmental Engineering, 5. https://doi.org/10.1007/s41204019-0055-5, 2019

3. Eldokhri, A., \& Adam, A. Toxicity of Aqueous and Ethanol Extracts of Ginger (Zingiber officinale L.) Rhizome and Henna (Lawsonia inermis L.) Leaves on Mosquitoes (Anopheles and Culex) Larvae, 1-37, 2015

4. Kannan, U. S. Assessment of dyeing properties and quality parameters of natural dye extracted from Lawsonia inermis, 5(7), 62-70, 2015

5. Omer kamal alebeid, tao Z. and ahmed I. S. (2015). Dyeing and Functional Finishing of Cotton fabric Using henna Extract and TiO2 Nano-sol, 16(6), 1303-1311. https://doi.org/10.1007/s12221-015-1303-3 